\title{
Unheralded Submarine Groundwater Discharge
}

\author{
Chen-Tung Arthur Chen ${ }^{1,2 *}$, Ting-Hsuan Huang ${ }^{1}$, Hon-Kit Lui ${ }^{1}$ and Jing Zhang ${ }^{3}$ \\ ${ }^{1}$ Department of Oceanography, National Sun Yat-sen University, Taiwan \\ ${ }^{2}$ Institute of Marine Chemistry and Environment, Zhejiang University, China \\ ${ }^{3}$ Environmental Biology and Chemistry, Graduate School of Science and Engineering, University of Toyama, Japan
}

Submission: September 16, 2019; Published: October 09, 2019

Corresponding author: Chen-Tung Arthur Chen, Department of Oceanography, National Sun Yat-sen University, Kaohsiung 80424, Taiwan

Keywords: Submarine groundwater discharge; Nutrients; $\mathrm{pCO}_{2}$; Dissolved inorganic carbon; Alkalinity; Primary production; Carbon cycle

Abbreviations: SGD: Submarine Groundwater Discharge; DOC: Dissolved Organic Carbon; DIC: Dissolved Inorganic Carbon; DO: Dissolved Oxygen; TA: Alkalinity; $\mathrm{pCO}_{2}$ : Partial Pressure of $\mathrm{CO}_{2}$

\section{Opinion}

Land meets the ocean in the coast zone, which is of great importance for aquaculture, fisheries, tourism and transportation, among other things. As fifty percent of the world population lives within $100 \mathrm{~km}$ of the coast, human activities have put tremendous pressure on the coastal environment. For instance, excess nutrients that are generated by agriculture and present in domestic waste have been discharged into the oceans by rivers, making many coastal regions hypoxic or even anoxic. Most people do not realize that a substantial fraction of the freshwater on land enters the oceans directly from the seabed, unseen by human eyes. This process is called submarine groundwater discharge (SGD) [15]. Burnett and coworkers [6] were among the first to provide a ballpark estimate that the amount of SGD is $0.2-10 \%$ of global river discharge. Since groundwater has been frequently in contact with soil and bedrock for hundreds of years, if not longer, some of the dissolved organic carbon (DOC) in the groundwater as well as particulate organic carbon and $\mathrm{CaCO}_{3}$ in the soil and bedrock are expected to have decomposed or dissolved.

These processes release nutrients, alkalinity (TA), and dissolved inorganic carbon (DIC) into the groundwater while reducing its dissolved oxygen (DO) content and pH [7-11]. The partial pressure of $\mathrm{CO}_{2}\left(\mathrm{pCO}_{2}\right)$ in the groundwater normally exceeds the saturation level. The variation of DOC concentration depends on the balance between its decomposition in groundwater and its generation from soil and bedrock. Groundwater is isolated from the atmosphere but when it enters the oceans, supersaturated $\mathrm{CO}_{2}$ may be released to the atmosphere [12]. Excess nutrients that are carried by the SGD promote primary production, which reduces $\mathrm{pCO}_{2}$. Whether the SGD eventually functions as a carbon source or a sink into the receiving coastal waters cannot be determined a priori. Only recently did two investigations provide a preliminary answer. First, Chen and coworkers [13] estimated that the freshwater component of the SGD in Taiwan equals around $5.2 \%$ of the annual river discharge in Taiwan, where the over pumping of groundwater has been a serious problem.

Table 1: The N, P, Si, TA and DIC fluxes from the SGD and rivers in Taiwan.

\begin{tabular}{|c|c|c|c|}
\hline & SGD Flux $^{\mathbf{a}}\left(\mathbf{1 0}^{\mathbf{9}} \mathbf{\text { mol}}\right)$ & $\begin{array}{c}\text { River Flux }^{\mathbf{b}} \mathbf{( 1 0 ^ { 9 }} \\
\left.\mathbf{m o l}^{\mathbf{9}}\right)\end{array}$ & $\begin{array}{c}\text { SGD/Rivers } \\
\text { (\%) }\end{array}$ \\
\hline $\mathrm{N}$ & $1.18 \pm 0.83$ & $9.31 \pm 6.29$ & 12.7 \\
\hline $\mathrm{P}$ & $0.0093 \pm 0.0065$ & $1.06 \pm 0.47$ & 0.9 \\
\hline $\mathrm{Si}$ & $0.68 \pm 0.48$ & $7.34 \pm 2.05$ & 9.3 \\
\hline $\mathrm{TA}$ & $34 \pm 24$ & $161 \pm 19$ & 21.1 \\
\hline $\mathrm{DIC}$ & $32 \pm 22$ & $163 \pm 20$ & 19.6 \\
\hline
\end{tabular}

a Taken from [14]; ${ }^{b} \mathrm{~N}$ and $\mathrm{P}$ are taken from the EPA (https://www.epa. gov.tw/); Si, TA, and DIC are unpublished data of C.T.A. Chen

Even in such an environment, the SGD is substantial. Additionally, Wang and coworkers [14] indicated that in Taiwan, the SGD exports N, P, Si, TA, and DIC in amounts equivalent to $12.7,0.9,9.3,21.1$ and $19.6 \%$, respectively, of those in riverine fluxes (Table 1). Finally, Wang and coworkers found that primary production, supported by nutrient outflows from the SGD in Taiwan and from the Jiulong River across the Taiwan Strait, do not suffice to compensate for the DIC that is supplied by the SGD. Consequently, the SGD helps to make the coastal waters in Taiwan and Jiulong River heterotrophic, releasing $\mathrm{CO}_{2}$ to the atmosphere. Unfortunately, such a conclusion cannot be generalized to a region 
- let along to all coastal seas around the world - because the total area of Taiwan $\left(35,873 \mathrm{~km}^{2}\right)$ and the Jiulong River watershed $\left(14,740 \mathrm{~km}^{2}\right)$ is only $0.034 \%$ of the area of all land on earth. Whereas rivers have been extensively studied, only a handful of reports concerning nutrients, TA and DIC fluxes have focused on SGD [15-21].

Worse, the relevant literature is mainly concerned with the flux per unit area of discharge into oceans. Such data cannot be extrapolated to the global oceans as the discharge area is unknown. On the other hand, the yield, which is the flux per unit area of the river basin, can be extrapolated from readily available river basin data. According to the latest tabulation of Wang et al. [14] yield data for N, P, Si, TA and DIC are available only for Taiwan, the Jiulong River and the Pearl River. An accurate estimate of the SGD flux is essential to predicting coastal environments in an era of rapid global change but most - if not all - coastal biogeochemical models have no SGD component. Substantial errors may arise if SGD is ignored, especially in estuaries, bays, inland seas, deltas and salt marshes. Since the areas of thousands of river basins worldwide are known, with a knowledge of the yield the global amount of material flux by SGD can be reasonably estimated and its effect on the coastal biogeochemistry better evaluated.

\section{Acknowledgement}

This work was supported by the Ministry of Science and Technology of the Republic of China (MOST 108-2611-M-110-016 and 108-2611-M-110-017).

\section{References}

1. Church T M (1996) An underground route for the water cycle. Nature 380: 579-580.

2. Taniguchi M, Burnett $\mathrm{W}$ C, Cable J E, Turner J V (2002) Investigation of submarine groundwater discharge. Hydrol Process 16: 2115-2129.

3. Zhang J and Satake H (2002) Submarine groundwater seepage in Toyama. Aquabiology 24: 294-301.

4. Moosdorf N, Stieglitz T, Waska H, Durr H H, Hartmann J (2015) Submarine groundwater discharge from tropical islands: a review. Grundwasser 20: 53-67.

5. Slomp C P and Van Cappellen P (2004) Nutrient inputs to the coastal ocean through submarine groundwater discharge: controls and potential impact. Journal of Hydrology 295(1-4): 64-86.

6. Burnett W C, Taniguchi M and Oberdorfer J (2001) Measurement and significance of the direct discharge of groundwater into the coastal zone. Journal of Sea Research 46: 109-116.

7. Moore W S (2010) The effect of submarine groundwater discharge on the ocean. Annu Rev Mar Sci 2: 59-88.
8. Cai W J, Wang Y C, Krest J and Moore W S (2003) The geochemistry of dissolved inorganic carbon in a surficial groundwater aquifer in North Inlet, South Carolina, and the carbon fluxes to the coastal ocean. Geochimica et Cosmochimica Acta 67(4): 631-639.

9. Liu Q Dai M, Chen W, Huh C A, Wang G et.al. (2012) How significant is submarine groundwater discharge and its associated dissolved inorganic carbon in a river-dominated shelf system? Biogeosciences 9: 1777-1795.

10. Cai P H, Shi X M, Hong Q Q, Li Q, Liu L F, et. al. (2015) Using Ra-224/Th228 disequilibrium to quantify benthic fluxes of dissolved inorganic carbon and nutrients into the Pearl River Estuary. Geochimica et Cosmochimica Acta 170: 188-203.

11. Wang G, Han A, Chen L, Tan E and Lin H (2018) Fluxes of dissolved organic carbon and nutrients via submarine groundwater discharge into subtropical Sansha Bay, China. Estuarine, Coastal and Shelf Science 207: 269-282.

12. Szymczycha B, Maciejewska A, Winogradow A and Pempkowiak J (2014) Could submarine groundwater discharge be a significant carbon source to the southern Baltic Sea? Oceanologia 56(2): 327-347.

13. Chen C T A, Zhang J, Peng T R, Kandasamy S, Wang D et.al. (2018) Submarine groundwater discharge around Taiwan. Acta Oceanlologica Sinica 37(6): 18-22.

14.Wang S L, Chen C T A, Huang T H, Tseng H C, Lui H K, et al. (2018) Submarine Groundwater Discharge helps making nearshore waters heterotrophic. Scientific Reports (8): 11650.

15. Gu H Q, Moore W S, Zhang L, Du J Z and Zhang J (2012) Using radium isotopes to estimate the residence time and the contribution of submarine groundwater discharge (SGD) in the Changjiang effluent plume, East China Sea. Continental Shelf Research 35: 95-107.

16. Wang X L, Dua J Z, Ji T, Wen T Y, Liu S M, et.al. (2014) An estimation of nutrient fluxes via submarine groundwater discharge into the Sanggou Bay-A typical multi-species culture ecosystem in China. Marine Chemistry 167: 113-122.

17. Moore W S, Blanton J O and Joye S B (2006) Estimates of flushing times, submarine groundwater discharge, and nutrient fluxes to Okatee Estuary, South Carolina. J Geophys Res-Oceans 111: C09006.

18. Wang G Z, Wang Z Y, Zhai W D, Moore W S, Li Q,et al. (2015) Net subterranean estuarine export fluxes of dissolved inorganic C, N, P, Si, and total alkalinity into the Jiulong River estuary, China. Geochimica et Cosmochimica Acta 149: 103-114.

19. Hong Q Q Cai P H, Shi X M, Li Q and Wang G Z (2017) Solute transport into the Jiulong River estuary via pore water exchange and submarine groundwater discharge: New insights from Ra-224/Th-228 disequilibrium. Geochimica et Cosmochimica Acta 198: 338-359.

20. Liu Q Charette M A, Breier C F, Henderson P B, McCorkle D C, et.al. (2017) Carbonate system biogeochemistry in a subterranean estuary - Waquoit Bay, USA. Geochimica et Cosmochimica Acta 203: 422-439.

21. Liu J A, Du J Z, Wu Y and Liu S M (2018) Nutrient input through submarine groundwater discharge in two major Chinese estuaries: the Pearl River Estuary and the Changjiang River Estuary. Estuarine Coastal Shelf Science 203: 17-28. 
Your next submission with Juniper Publishers will reach you the below assets

- Quality Editorial service

- Swift Peer Review

- Reprints availability

- E-prints Service

- Manuscript Podcast for convenient understanding

- Global attainment for your research

- Manuscript accessibility in different formats ( Pdf, E-pub, Full Text, Audio)

- Unceasing customer service

Track the below URL for one-step submission https://juniperpublishers.com/online-submission.php 